\title{
継手の効果とひびわれの影響を考慮した トンネル縱断方向の耐震設計法
}

\author{
田中 努 ${ }^{1} \cdot$ 鈴木 $^{\text {猛康 }}{ }^{2}$ \\ 1フェロー会員 エイト仆本技術開発 東京支社 保全·而震·防災部（干164-8601 東京都中野区本町5-33-11） \\ E-mail : tanaka-tsu@ej-hds.co.jp \\ 2フェロー会員 山梨大学教授 医学工学総合研究部社会システム工学系（†400-8511 山梨県甲府市武田 4-3-11） \\ E-mail : takeyasu@yamanashi.ac.jp
}

\begin{abstract}
本論文では，まず，継手の開きを地盤が拘束する影響について筆者らが提案した評価方法を見直し，多くの実トン ネルにおける継手岡性の変化量と動的解析結果に現れる地震時応答への影響を再評価した. 次に, ひびわれ発生によ る覆工岡性の変化を考慮して解析を実施し, 解析結果に現れる地震時灾答の変化を評価した. 最後に, これらに基づ き，地震時のトンネル紷断方向の地盤ひずみがあまり大きくならない場所では，継手に過度に期待せずに，縜断方向 の鉄筋を，その引張降伏強度を覆エコンクリートの引張強度を上回るように配置すること，地盤ひずみが大きくなる 場所では，地盤の継手の開きを拘束する影響を考慮して継手を配置し，覆工の平均ひずみを低減させることを基本と する而震設計法をまとめた.
\end{abstract}

Key Words : tunnel, longitudinal direction, seismic design, lining cracks, stiffness, joint

\section{1. はじめに}

トンネル縦断方向の而震性は, 地下水位下に構築される 都市トンネルには重要な性能である. 特に水底に薄い土か ぶりで構築される沈埋トンネルでは, 浸水は致命傷となる ため, 沈埋函を連結寸る施工継手を可撓構造にして, トン ネルに生じる変位を吸収し, 函体の縦断方向の引張力を軽 減させている. しかしその継手の開きが過大にならないよ う, 岡性を調整して継手の止水性を確保する. そのため函 体の縦断方向鉄筋や函体の洋上製作で用いる鋼款の鋼板 を抵抗部材として設計し，而震性を確保している

逆に，シールドトンネルでは， $1 \mathrm{~m}$ 程度の間隔でリング 継手が存在し, リング継手の引張岡性がセグメントに比べ て十分に小さいため, セグメント幅分の地盤の引張ひずみ がリング継手に集中すると考え, リング継手のシールによ る止水性と継手金物の安全性が確保できるよう設計して (る3),4).

一方，開削トンネルは，基本的にはコンクリートを連続 して打設する継手のない構造であり，古くは，トンネル縦 断方向の而震性を確保寸るために, 縦断方向鉄筋の量を増 加させる而震対策が行われた. しかし地盤急変部を通過す る場合は, 延長 $20 \mathrm{~m}$ 程度毎のコンクリートの施工目地を 伸縮可能な構造に変え, 止水板等で止水性を確保しつつ,
トンネル縦断方向の引張力を低減させた上で, 不足分をト ンネル縦断方向鉄筋で抵抗する対策が取られた ${ }^{5)}$. 近年は, さらに短い $10 \mathrm{~m}$ や $5 \mathrm{~m}$ の間隔で伸縮目地を設け, トンネル 躯体の縦断方向鉄筋量は横断方向の主筋に対寸る配力筋 のままに抑えたり，身区体コンクリートのひびわれ発生を抑 えるところまで, 積極的に伸縮目地の変位吸収による引張 力の低下に期待する設計が行われる傾向がある.

このように, いずれのトンネルの耐震設計も, 継手や伸 縮目地による変位の吸収に期待して, トンネル躯体の縦断 方向の引張力を低下させる方法である.

しかしながら, トンネルと地盤が密着しているため, 継 手や伸縮目地に例えば $1 \mathrm{~cm}$ の開きを生じるには, 継手や 伸縮目地部分に地割れが生じるか, 広範囲で地盤とトンネ ル躯体との間に滑りが生じる必要がある. それらが生じな い場合は, 継手周囲のトンネルに密着している地盤が継手 の開きに抵抗する. 鈴木は, シールドトンネルのリング継 手の変位吸収について, 実測・模型実験・数值解析を行っ て調べ, 継手周囲の地盤のせん断抵抗により継手の開きが 拘束され，実際に発揮される継手剛性が構造のみの力学乇 デルから決定される岡性より高まることを示している6). このように, 継手や伸縮目地の変位吸収が, 現行の設計で 期待するほど大きくない場合は, トンネル躯体に設計值以 上の引張力が作用することになり, 新設トンネルの設計に おける配筋量の見直しや既設トンネルの而震性の再評価 
が必要になる.

なお，本論文では，この継手剛性の問題は，継手や伸縮 目地を有する全ての都市トンネルに共通寸るため, シール ドトンネルと開削トンネルを事例にあげている. また後述 の躯体のひびわれの問題は開削トンネルや沈埋トンネル およびシールドトンネルの二次覆工など連続した鉄筋コ ンクリート躯体に共通する問題であるが, 開削工法で構築 される大型トンネルに影響が大きいと考えられるため, こ れを主たる対象としている.

\section{2. トンネル縦断方向の耐震設計法と課題}

ここでは，1章で述べた継手の効果に関する指摘が現行 の耐震設計の中でどのような問題を引き起こすかを示し た. また, 継手の効果が小さければ覆工にひびわれが生じ る可能性が高まるため, ひびわれ発生後の挙動を設計で考 慮する方法を 3 章で述べるが，それを前提に，地盤ひずみ が小さい場所では継手に期待せずに覆工にひびわれが生 じることを許した設計ができると考え，その考え方を示し た.

\section{（1）耐震設計法と継手の問題}

世界で初めてトンネル縦断方向の耐震設計が行われた のは, 1972 年に開通した米国サンフランシスコ湾を横断 する BART-TUBE (Bay Area Rapid Transit : ベイエリア高 速鉄道) で, 湾内の軟弱地盤の地震時変位を想定した設計 であろう。わが国では，追って，1974 年の石油パイプラ イン技術基準や 1975 年の土木学会の沈埋トンネル耐震設 計指針 (案) により，トンネル縦断方向の耐震設計法が体 系的に明示され，実務に適用されていった。

トンネル縦断方向の而震設計法は, 上記の基準・指針で 応答変位法と呼ばれ, 地震時の周辺地盤の変位分布をトン ネルに作用させてトンネルの応答を求め, トンネルに生じ る断面力やひずみが許容值を下回るように構造を設計す る方法である.

トンネルには地盤とトンネルの相対変位と地盤ばね定 数に比例した力が作用寸るため, トンネルの岡性が高く変 形しない場合は大きな断面力が生じ, 抵抗力を確保するた めに大量の鉄筋が必要になる. しかし，トンネルに可撓継 手や伸縮目地を設けて変形し易くし地盤とトンネルの相 対変位が小さくなると，トンネル躯体に発生する断面力は 小さくなり少ない鉄筋量でも容易に抵抗できるようにな る.したがって, トンネルに可撓継手や伸縮目地を設けて, トンネル躯体の断面力を低減させる設計が行われる。

沈埋トンネルでは, トンネル函体の浮上・曳航・沈設・ 水圧接合の施工性から, 長さ $100 \mathrm{~m}$ 程度の函体の端部に設 置されるゴムガスケットを利用した可撓継手で対応する. したがってトンネル変位の吸収箇所が少ないため一力所 の可撓継手に生じる開きが大きく, 特にトンネル両側の陸 上部の換気塔との接合部では数 $\mathrm{cm}$ 以上の開きが想定され
て大伸縮可能な継手が必要になる場合がある.ただし，道 路トンネルの路面や鉄道トンネルの軌道の連続性確保の ために, 横断方向のせん断ずれを拘束した構造が工夫され ている.

開削トンネルの場合は，伸縮可能量の小さな目地を 10 〜20m 程度の間隔で設置することも可能であるが，対向 4 車線の道路トンネルの場合はトンネル幅が $30 \mathrm{~m}$ 強である ため, ブロックを並べたようなバラバラのトンネル構造に なり，長期的には不陸が起きそうである，そのため多数の スリップバーを設けたり, より連結性を高めるために伸縮 を許しつつ許容変位を超えると抵抗する連結鉄筋を配置 するなどの構造が工夫されている. 継手や伸縮目地の開き を抑制する必要がある場合は, それらを多数設置して少し ずつトンネル変位を吸収する必要があるため, 継手や伸縮 目地間隔は $5 \sim 10 \mathrm{~m}$ 程度とさらに短くなる.

シールドトンネルの場合は， $1 \mathrm{~m}$ 程度の間隔でリング継 手があるため, トンネル变位を分散して吸収できる構造で あるが，二次覆工を設けるとトンネル剛性が大幅に高まる ため，地盤急変部や立坑接続部などでは，可撓セグメント を設置する必要が生じる場合がある.

このように，トンネル維断方向の耐震設計では，可撓継 手や伸縮目地の変位吸収に期待しているが, 継手の変位吸 収の効果が設計で考えているより小さいという指摘があ り ${ }^{6}$ ，筆者らは過去に新たな解析を行ってこの挙動を確認 した ${ }^{13)}$. 継手の変位吸収効果が設計で期待しているより小 さければ，より多数の継手を設ける必要がある. しかし， 継手は, 工費・工期の増加や長期的な防水性が連続した卜 ンネル躯体より低くなるなどの問題もあるため, 継手ばか りに依存するのは必ずしも得策ではない，例えば工費は, 表-1のようなオーダーで増加する.

表-1＼cjkstart開削工法の道路トンネル躯体と継手の工事費の例

\begin{tabular}{|l|r|l|}
\hline \multicolumn{1}{|c|}{ 部 位 } & \multicolumn{1}{|c|}{ 工事費 } & \multicolumn{1}{|c|}{ 備 考 } \\
\hline 躯 体 & 13500 万円 & 対向4車, 10m 当たり \\
\hline 可撓継手 & 2000 万円 (15\%) & 1箇所 \\
\hline 伸縮目地 & 200 万円 $(1.5 \%)$ & 1箇所, 刏ップバー式 \\
\hline
\end{tabular}

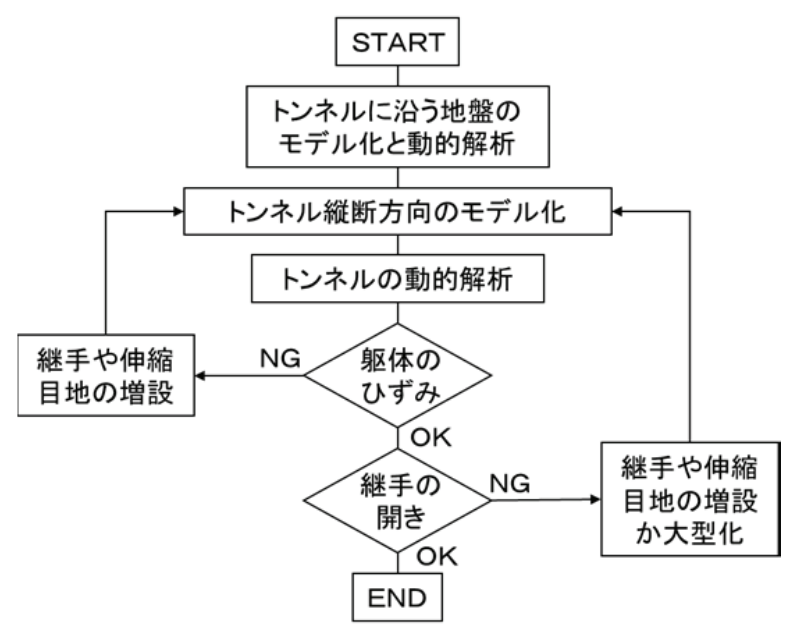

図-1トンネル縦断方向の而震設計の流れ 
本論文では，3 章で，この挙動の物理的な解釈と影響範 囲を定量的に示し，さらに実トンネルとの比較を行って， 影響の大きさを明らかにしている。

\section{（2）継手を用いない考え方を含めた耐震設計の流れ}

道路等の比較的大断面のトンネルの縦断方向の而震設 計は, 常時の設計, 横断方向の而震設計の後に行われ, 多 くの場合は図-1 のように，地盤とトンネルの動的解析を 行って継手を設ける流れになる.

トンネルの延長が長い場合は, トンネルに沿う地盤構造 や土質の変化の影響が地震時の地盤変位分布に局所的に 現れるが, 設計基淮類に示される「狭義の応答変位法」で は, 着目地点の地盤条件が水平に広がる一様地盤を考え, トンネルに沿う地震時の地盤変位分布を考慮できないた めに, 地盤モデルの動的解析が必要となる. 一方, トンネ ルが換気立坑のように地上部分を有する構造物と接続す る場合は, 立坑の慣性力による振動を考慮しなければなら ないため, トンネルと立坑の相互作用を考慮した動的解析 が必要である.しかしこれらの動的解析では，トンネルの 質量を無視しているため, 時々刻々変化する地盤の変位分 布に対する, 時々刻々のトンネルの静的応答変位を求める 「広義の応答変位法」である.

トンネル縦断方向の而震設計では, トンネルの構造と材 料から, 軸引張力が支配的な要因となる. トンネルの軸引 張力が最大になるのは, 地盤変位分布の形状にもよるが, およそ地盤のトンネル軸方向 (水平方向) の引張ひずみが 最大のときに生じる. したがって, 着目地点の地盤の水平 方向の最大引張ひずみが分か水ば, その位置のトンネルに 生じる引張ひずみの程度が推定できる. 詳しくは 3 章で述 べるが，地盤のひずタがトンネルに伝わる率 (伝達率) は 1 以下である.つまり剛性の高いトンネルは伝達率が小さ いが, 躯体にひびわれが生じると剛性が低下し伝達率が大 きくなるため, トンネルに発生するひずみは地盤の最大ひ ずタに近づいていくが，これを超えることはない．したが って, 地盤の水平方向の引張ひずみが，その位置のトンネ ルに生じうる最大ひずみの目安となる.

これらより, 地盤に生じる水平方向の最大ひずみに応じ て，トンネルの状態を次のように分けて考えることができ る. ただし, 構造急変部等の特殊部分はひずみ分布が複雑 になるので, 詳細な部分モデルによる動的解析等が必要で ある。

a) 地盤の最大水平方向ひずみがコンクリートのひびわれ 発生ひずみを下回る地点：このような地点では, トン ネル躯体のコンクリートにひびわれが生じないため, 原 則として図-1 のトンネル縦断方向の動的解析以下の流 れは不要となる. ただし, 施工時の温度応力や, 施工後 の乾燥収縮, 地盤沈下, 比較的大きな地震の経験などに より 既にトンネル躯体にひびわれが発生している場合 は，次のb)と同様になる.

b) 地盤の最大水平方向ひずみがコンクリートのひびわれ 発生ひずみを上回るが鉄筋の降伏ひずみを下回る地
点：原則として，トンネル縦断方向の鉄筋の引張降伏 耐力をコンクリートのひびわれ発生荷重より大きくし 図-1 のトンネル縱断方向の動的解析以下の流孔は不要 となる. ただし，トンネル䋡断方向の鉄筋量をここまで 増やさない場合は動的解析以下の流れが必要となる. 卜 ンネル縦断方向の鉄筋の引張降伏耐力をコンクリート のひびわれ発生荷重より大きくする理由は 4 章で詳述 する.

c) 地盤の最大水平方向ひずみが鉄筋の降伏ひずみを上回 る地点：図-1の流れの通り。ただし，3章で述べる継 手周囲の土のせん断抵抗ばねを考慮しなければならな い.

上記の a) は, トンネルに作用する地震の影響は周辺地 盤の変位であり,トンネルがその地盤変位よりも大きな変 位をすることはないという応答変位法の考え方に基づい て, 地盤の最大水平方向ひずタがコンクリートのひびわれ 発生ひずみを下回るならば, トンネルにはひびわれが発生 しないという理屈である.

上記の b) は，鉄筋コンクリートのひびわれ部の挙動を 考慮したものである. 鉄筋コンクリート部材に引張りひず みが生じて徐々に増加していくとき，ひびわれが発生し， ひびわれ面から深部に向かって鉄筋とコンクリートの付 着が徐々に切れて, 鉄筋が抜け出し自由に伸びるようにな る. このとき, 鉄筋量が多い場合は, 付着力によってコン クリートに引張力が伝達され, やがて別の場所にひびわれ が発生する.これが繰り返されれば,ひびわれが分散して 発生し，1つのひびわれ幅は小さくなる. 逆に鉄筋量が少 ない場合は, 付着力の和も少なく, コンクリートに伝達さ れる引張力も少なく，他にひびわれが発生しない．したが って最初にひびわれの生じた箇所て鉄筋が降伏し，そのひ びわれだけが大きく開くことになる。このことは, シール ドトンネルの二次覆工でも注意が必要である. もともと継 手間隔が短く柔軟な構造であるのに，トンネル縦断方向の

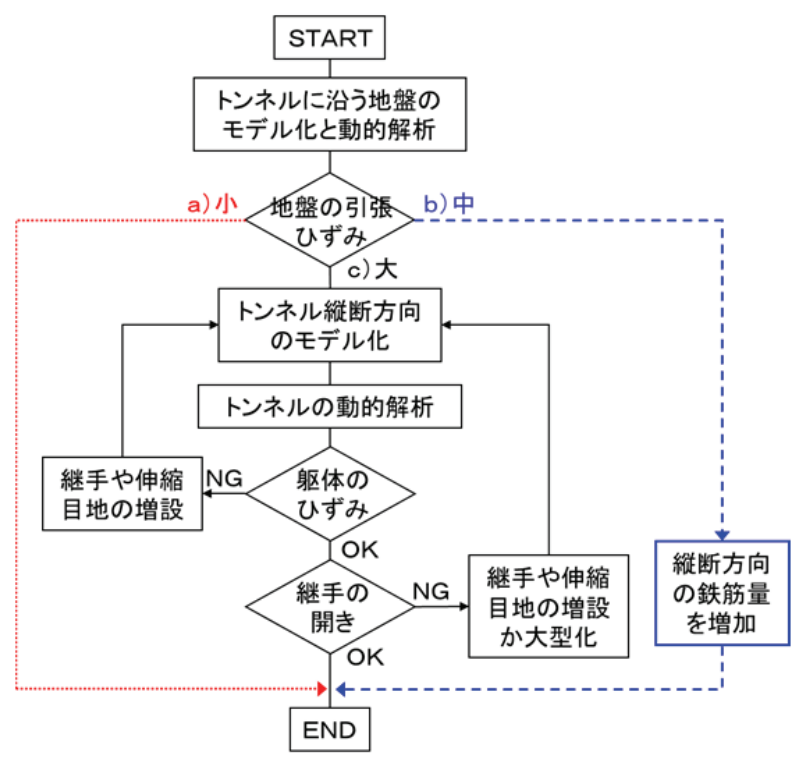

図-2 継手を用いない考え方を含めた而震設計の流れ 
鉄筋量が少ない二次覆工を設けると, 何らかの理由で最初 にひびわれの発生した位置のリング継手だけが開く危険 性がある。

上記の a) c) の考え方を加えたトンネル縦断方向の耐 震設計の流孔は図-2 のようになる. 図-1 に比べ地盤の動 的解析を行った後, 地盤の水平方向の最大引張ひずみの大 きさにより a)〜c) の 3 つの方向に別れる部分が加わって いる.

今日, 通常の実務設計でも, 解析ソフトとコンピュータ を駆使した高精細の 3 次元 F EMモデルによる動的解析 が行われることがあるが, 地震動や地盤の情報の不確かさ を考えると, 特に設計初期の而震構造計画の段階では, 図 -2 の地盤の動的解析により地盤ひずみを把握した段階で のエンジニアリング・ジャッジが望まれる.

\section{3. 継手周囲地盤の抵抗の評価}

ここでは, 可撓継手や伸縮目地周囲の土の抵抗の物理的 な解釈を示して影響範用を定量的に示し, さらに実トンネ ルとの比較を行って, 設計に与える影響の大きさを明らか にした. 継手周囲の土の抵抗力や継手近傍の覆工との間の 滑りなどの地盤の挙動については，文献 13)に詳述したた め,ここでは省略し現行の耐震設計での考慮のし方に絞る.

なお, 西岡らも, トンネル縦断方向の梁ばねモデルと F EMモデルの動的解析結果を比較し, 梁ばねモデルでは継 手周辺の軸ひずみが異常に低減してしまい，F EM結果と 整合しないことを示している ${ }^{14)}$.それがここで取り上げる 継手が開きにくくなる現象であり，設計で考慮する方法の 開発が望まれている.

\section{（1）シ一ルドトンネルに対する継手周囲の土の抵抗ばね}

横浜市にあるシールドトンネルにおいて, セグメント本 体とリング継手部で, 地震時のトンネル縦断方向の伸縮が 観測されている6). 鈴木は，この観測值のセグメントと継 手の伸縮量の比から, 継手とセグメントのばね定数の比を 求めた. その結果, 観測值から逆算される継手のばね（地 中でのばね）定数が, 設計で継手構造から算定される継手 のばね（空気中でのばね）定数より大きいことを示した. さらに, このばね定数の違いは継手周囲の土のせん断抵抗 が加わったことによるものであると仮定し, 継手部分モデ ルやトンネル全体モデルの模型実験と 3 次元 F EM解析 を行い，土のせん断抵抗ばね定数 $K g$ を式(1)で表した ${ }^{6)}$.

$$
K g=\alpha \cdot \pi G D L
$$

ここで， $\alpha$ は係数， $\pi$ は円周率，Gは土のせん断弾性係 数, Dはシールドトンネルの外形, Lはセグメントの幅で ある.

この土のせん断抵抗ばね定数 $\mathrm{Kg}$ は, 継手が開くことを 拘束するように働くので, 通常の設計で考えている継手構

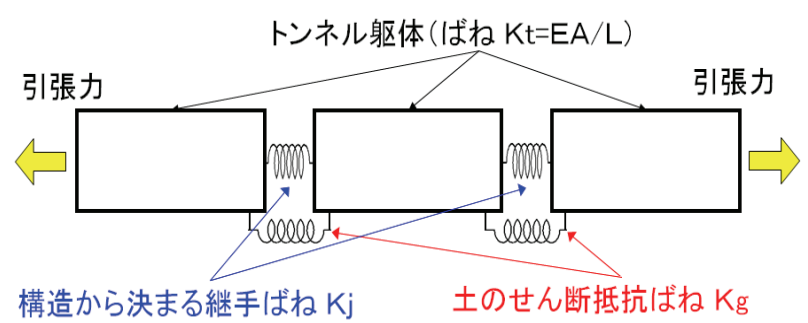

図-3 土のせん断抵抗ばねのイメージ

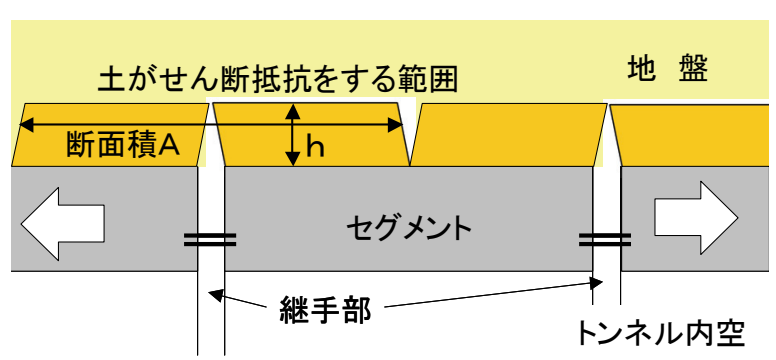

図-4＼cjkstart継手周囲の土がせん断抵抗をする範囲

造のみの力学モデルから決定される継手のばね (空気中で のばね) 定数 $K j$ およびトンネル躯体のばね定数 $K t$ の関係 は，図-3 のように表せる，つまり，継手のばねは見かけ 上設計で考えている構造のみの力学モデルから決定され る継手ばね（気中でのばね）定数 $K j$ と土のせん断抵抗ば ね定数 $K g$ の和となる.

式(1)は, 継手の周りの土のせん断抵抗ばね定数を決定す る因子で構成されたもので， $\pi D L$ はセグメント 1 リング 分の外周面積 $A$ であるから, 式(1)の $\pi G D L$ は, 土がせん 断抵抗を示寸範囲のせん断岡性 $G A$ を意味することにな る. 係数 $\alpha$ は長さ分の 1 の次元を持つので，土のせん断抵 抗ばねのメカニズムを図-4 のように考えると，式(1)のば ね定数 $K g$ は式(2)のように書くことができる.

$$
K \boldsymbol{g}=G A / h
$$

図-4 は, トンネルの継手が開くときに, 周囲の土がせ 几断抵抗を示す範囲のイメージである. 土のせん断ひずみ の分布は徐々に変化し分散し図のように明確に分かれな いと考えられるが，式(2)の概念を表現している. 式(2)の hは，図-4 のせん断抵抗をする範囲の高さに相当する.

鈴木は論文 ${ }^{6}$ の中で式(1)の係数 $\alpha$ は実務上 0.074 として よいと述べている. これを式(2)の $h$ に換算すると, 逆数で あるから $13.5 \mathrm{~cm}$ となる. つまり, トンネルの周囲の厚さ 13〜14cm の土が継手の開きにせん断抵抗をするのに等し い抵抗力が発現されるということになる.

\section{（2）開削トンネルの継手周囲の土のせん断抵抗ばね}

筆者らは，開削トンネルの継手を対象に，TDAPIIIを用 いた平面ひずみモデルの静的解析により, 継手周囲の土の せん断抵抗ばねの評価を行った. モデルは, 継ぎ手近傍の 
幅 $13 \mathrm{~m} \times$ 長さ $5 \mathrm{~m}$ の範囲である. 結果の詳細は, 文献13) に 示した.

この解析において, 継手要素の伸びを $d_{j}$, 隣接する卜 ンネル躯体要素の伸びを $d_{t}$ とすると，伸びの比 $r$ はばね 定数の比の逆数になる.つまり,

$$
\begin{gathered}
r=d_{j} / d_{t}=K_{t} / K_{j e q} \\
K_{j e q}=K_{j}+K_{g}
\end{gathered}
$$

ここで $K_{t}$ はトンネル躯体のばね定数， $K_{\text {jeq }}$ は見かけの 継手ばね水定数 $K_{j e q}$ で, 構造のみの力学モデルから決定され る継手ばね定数 $K_{j}$ と継手周囲の地盤のせん断抵抗ばね定 数 $K_{g}$ の並列ばねである. この解析から逆算される継手の ばね定数は, 土のせん断抵抗の影響を含んだ見かけの継手 ばね定数である.

また，この解析では，継手構造から決まる継手のばね定 数 $K_{j}$ をトンネル躯体のばね定数 $K_{t}$ の $5 \%$ にたため,

$$
K_{t} / K_{j}=20
$$

これらの関係から，土のせん断抵抗ばね定数 $K_{g}$ が式(6) で求まる.

$$
K_{g}=(20 / r-1) \cdot K_{j}
$$

以上の式(3)の $r$, 式(6)の $K_{g}$, 式(2)の $h$ を表-2に示した. 土のせん断抵抗の範囲の面積は, トンネル横断方向には単 位奥行きの意味で $0.1 \mathrm{~m}$, 縦断方向には前述のシールドトン ネルの場合と同じ1mとした。

表-2 より，土がせん断抵抗をする範囲の高さ hは 1 〜 $18 \mathrm{~cm}$ で，地盤が硬いほど範囲 $h$ は高くなる。前述のシー ルドトンネルの場合の 13〜14cm より広い幅で変化するが, 高々 $18 \mathrm{~cm}$ 程度までのようである.

\section{（3） 3 次元F EMモデルによるシールドトンネルの継手 周囲の土のせん断抵抗ばね}

トンネルが大断面の場合は，トンネル上下端での地盤変 位が異なるので，3次元F EMモデルを用いて，その影響

表-2 せん断抵抗ばね定数と高さ

\begin{tabular}{|c|c|c|c|}
\hline $\begin{array}{c}\text { 地盤のVs } \\
(\mathrm{m} / \mathrm{s})\end{array}$ & $r$ & $\begin{array}{c}K g \\
(\mathrm{kN} / \mathrm{m})\end{array}$ & $h(\mathrm{~m})$ \\
\hline 50 & 12.59 & 37140 & 0.010 \\
\hline 100 & 12.22 & 40170 & 0.038 \\
\hline 200 & 10.65 & 55400 & 0.111 \\
\hline 300 & 8.92 & 78380 & 0.176 \\
\hline
\end{tabular}

表-3 せん断抵抗ばね定数と高さ（上中下 4 箇所の平均）

\begin{tabular}{|c|c|c|c|}
\hline $\begin{array}{c}\text { 地盤のVs } \\
(\mathrm{m} / \mathrm{s})\end{array}$ & $r$ & $\begin{array}{c}K g \\
(\mathrm{kN} / \mathrm{m})\end{array}$ & $h(\mathrm{~m})$ \\
\hline 50 & 9.58 & 1359000 & 0.045 \\
\hline 100 & 6.16 & 2810000 & 0.086 \\
\hline 200 & 2.54 & 8593000 & 0.113 \\
\hline 300 & 1.45 & 16040000 & 0.136 \\
\hline
\end{tabular}

を含んだ見かけの継手のばね定数を確認した. 前述(2)の解 析と同じくTDAPIIIを用いて, 静的解析を行った. 解析モ デルは, 幅 $150 \mathrm{~m} \times$ 地盤厚 $25 \mathrm{~m} \times$ 長さ $25 \mathrm{~m}$ とした. トンネル は外径 $5.05 \mathrm{~m}$ のシールドトンネルで，土被り厚を $11 \mathrm{~m}$ ，セ グメントは幅 $1 \mathrm{~m} \times$ 厚さ $25 \mathrm{~cm}$ とした. 結果の詳細は, 文献 13) に示した.

この解析において，表-2 と同様に，式(3)の $r$, 式(6)の $K_{g}$, 式(2)の $h$ 求め, 表-3 に示した. 土のせん断抵抗の 範囲の面積は, 式(1)に合わせて, トンネル横断方向に $\pi D$, 縦断方向にはセグメント幅 $1 \mathrm{~m}$ である.

表-3 より，土がせん断抵抗をする範囲の高さ hは 4〜 $14 \mathrm{~cm}$ で, やはり地盤が硬いほど範囲は高くなる. 前述の シールドトンネルの場合の $13 \sim 14 \mathrm{~cm}$ より広い幅で変化す るが，14cm 程度までのようである.

\section{（4）継手周囲の土のせん断抵抗ばねの算定}

前述(1) (3)の土のせん断抵抗の範囲高さをまとめると, 図-5 のようになる．このとき，せん断抵抗する範囲の土 の面積 $A$ はトンネル周長×トンネル縱断方向長さ $1 \mathrm{~m}$ であ る. 高さ $h$ は幅があり, これらの結果から定式化すること はできず, 今後の地震観測記録の分析やより綿密な解析が 必要であると考える. しかし, 高々 $15 \mathrm{~cm}$ 程度までのよう であること，設計上大きめの高さ $h$ 考慮する方が安全側

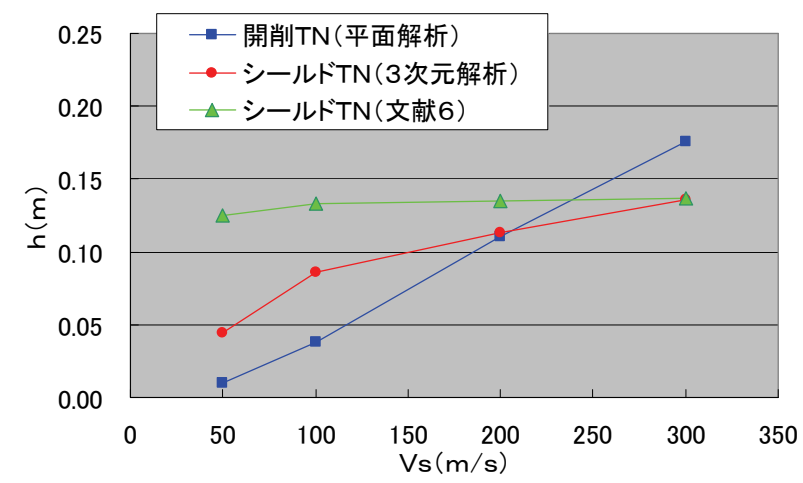

図-5 土のせん断抵抗範囲の高さ

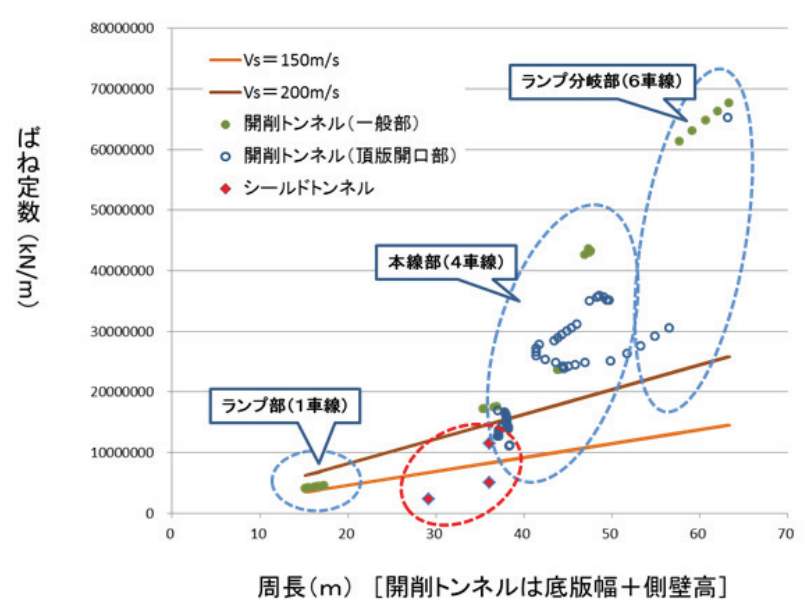

図-6＼cjkstart実際の道路トンネルに対する継手のばね定数 
であることを考慮すると，当面は， $h=15 \mathrm{~cm}$ として，式 (2)と式(4)により継手周囲の土のせん断抵抗ばねを考慮す る方がよいと思われる。

実際の道路トンネルに対寸る継手のばね定数を評価し て,この継手の開きを拘束する地盤の抵抗ばねとの比較を， 図-6に示した. 対象としたトンネルは, 対向 4 車 2 室の 開削トンネルで，ランブ部の 1 車線区間と分肢・合流部の 6 車線区間，さらに 1 車線と 2 車線のシールドトンネルで ある. 継手周囲の地盤ばねは，式(2)を用い，地盤のせん断 波速度 Vs を地震時の等価剛性を想定して 2 種類設定した (実線)。開削トンネルは，埋め戻しであることに配慮し て継ぎ手の開きに抵抗する地盤ばねを下側半分が有効と 仮定した.

同図によると，断面が小さいトンネルでは, 構造のみの 力学モデルから決定される継手のばね (気中でのばね) 定 数と同程度の大きさの継手周囲の地盤の抵抗ばねが存在 することになり，実際に効果を発揮する継手ばね（地盤中 のばね）定数は，設計で考えているばね定数の 2 倍程度に なると考えられる. 断面の大きなトンネルでは，3〜 5 割 増し程度であるが，無視できない大きさである. この通り の現象が起きているとすると, 既設トンネルでは, 継手は 想定より開かずに，トンネル躯体に想定以上の引張力が作 用しひびわれが生じるものと危惧される.

\section{4. 躯体のひびわれによる剛性変化の評価}

3章で述べたように，継手によるトンネル躯体のひずみ や引張力の低減効果が, 設計で考慮しているほど期待でき ないとすると，さらに密な間隔で継手や伸縮目地を設置す るか, 鉄筋コンクリートの躯体にひびわれが発生する条件 での設計が必要になる. 前者は, 継手のばね定数を変えて 従来の方法で行えばよいが，後者の方法では，ひびわれが 発生した後のトンネル縦断方向の躯体のひずみと剛性の 関係が必要である、筆者等はこれを調べ，結果の詳細を文 献13) に示してあるので，ここでは現行の耐震設計法に取 り込むための要点のみを示す.

なお,ここで述べる地盤ひずみとトンネルひずみの関係 には，トンネル〜地艋間ばねや地盤変位分布の影響が大き い．しかし筆者らは，2章で述べたように，地盤の動的解 析を必須と考えており, その解析結果からトンネル〜地盤 間ばねの基になる地震時の地盤状態や地盤変位分布を求 めることを考えている．したがって，ここでは設計法とし てノモグラムのような汎用のチャートを示すのではなく, 例えば図-9は1つの代表的な例として示し, 設計時には対 象とする地盤と地震に対する図-9を作成する手順を考え る.

\section{（1）対象モデルと方法}

図-7のような開削工法による対向4車線の道路トンネル をモデルにした. トンネル縱断方向の鉄筋は, 多くの場合,

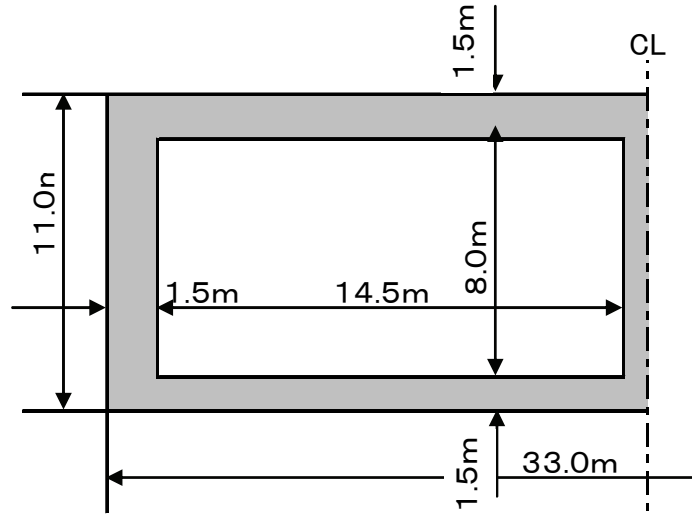

図-7トンネルモデル断面

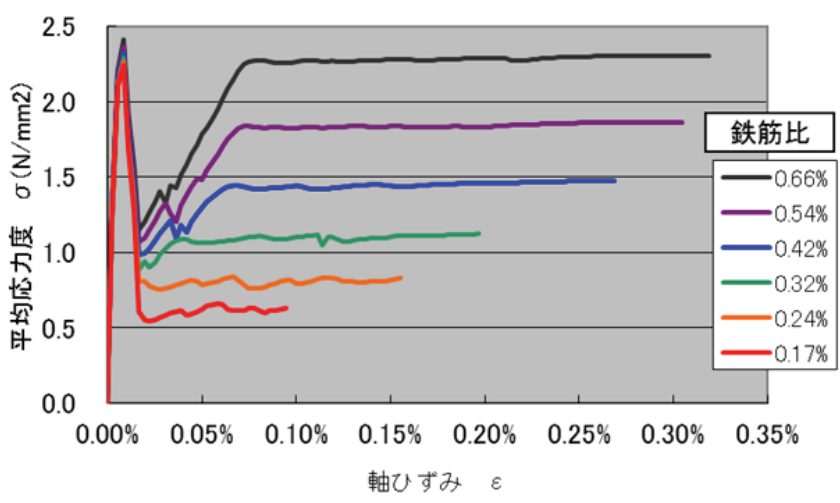

図-8トンネルの応力〜ひずみ関係

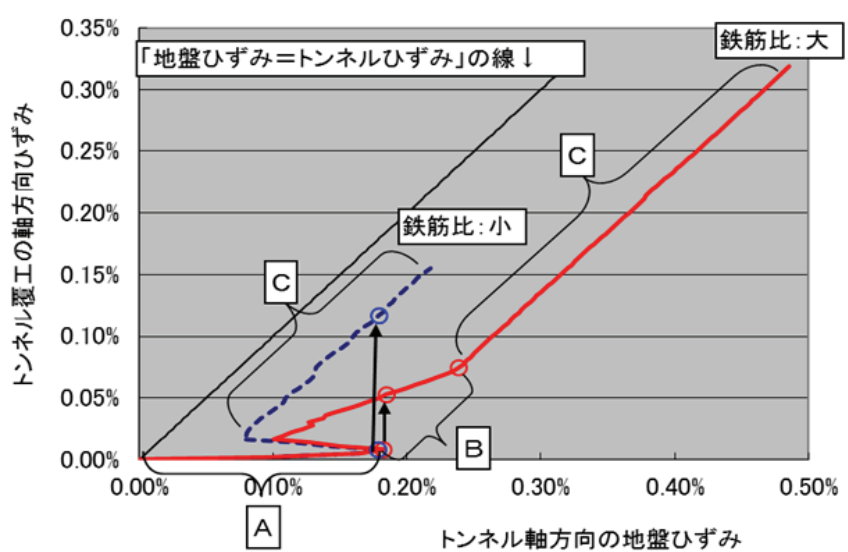

図-9＼cjkstart地艋ひずみと躯体ひずみの関係

横断方向の主筋の配力筋として主筋の $1 / 5$ 強の鉄筋量が配 置されるので，鉄筋比は大きくない．鉄筋量をD19～D35 -ctc200（鉄筋比 $p=0.17 \% \sim 0.66 \% ） に$ 変えた 6 ケースに ついて, 鉄筋コンクリート部材の「平均応力と平均ひずみ の関係を用いて表現される分散ひびわれモデル」に基づく プログラムWCOMD ${ }^{9,10)}$ 用いて, 棒部材を静的に引つ張 り，ひずみ増加に伴って発生する反力を求めた.

\section{（2）ひびわれによる剛性の変化}

トンネル躯体の軸ひずみと平均応力度の関係は図-8の 
ようになった. 躯体のひずみが地盤のひずみの増加に応じ て徐々に増加していく場合を考えると, 先ずコンクリート が抵抗し，ひびわれが生じて急激に反力が落ちるが，徐々 に鉄筋の反力が増し, 降伏応力度で一定となる様子が現れ ている.

前述の2章「(2) 継ぎ手を用いない考え方を含めた耐震 設計の流れ」の b) で述べた挙動は，この図の鉄筋比が $0.66 \%$ の場合と $0.17 \%$ の場合を比較すれば，一目瞭然であ ろう.

\section{（3）地盤ひずみとトンネルひずみの関係}

狭義の応答変位法の計算式を用いると，トンネル縦断方 向の地盤ひずみ $\boldsymbol{\varepsilon}_{g}$ とトンネルひずみ $\boldsymbol{\varepsilon}_{t}$ の関係は, 次のよ うに表せる. なお， $\alpha$ はひずみの伝達率，入は剛比係数で ある。

$$
\begin{gathered}
\varepsilon_{t}=\alpha \varepsilon_{g} \\
\alpha=1 /\left\{1+(2 \pi / \lambda L)^{2}\right\} \\
\lambda=\sqrt{(k / E A)}
\end{gathered}
$$

ここで, 地盤变位分布の波長は後述の事例に合わせて $L$ $=400 \mathrm{~m}$ ，地盤のばね $k=30000 \mathrm{kN} / \mathrm{m}^{2}$ とした．また式(9)の卜 ンネルの剛性 $E A$ は, 図-8の割線剛性 $E$ に図-7のモデルの 断面積を乗じて求めた.

図-9はトンネル縦断方向の地盤ひずみ $\boldsymbol{\varepsilon}_{g}$ とトンネル躯 体のひずみ $\boldsymbol{\varepsilon}_{t}$ の関係で, 次の(1)〜(5)の手順で求められる.

(1)図-7と図-8から，トンネルひずみ $\boldsymbol{\varepsilon}_{t}$ に対する岡性 $E A$ $\left(\boldsymbol{\varepsilon}_{t}\right)=\sigma / \boldsymbol{\varepsilon}_{t}$ が得られる.

(2)対象地点の地盤と対象トンネルに対する地盤ばね $k$ を 設計基淮から定めるか F EMにより算定すると，式(9) から剛比係数 $\lambda$ が得られる.

(3)地盤急変部の変位分布を近似できる正弦波の波長 $L$ を 設計基淮等に基づいて設定すると,式(8)からひずみの伝 達率 $\alpha$ が得られる。

(4)上記(1)で着目したトンネルひずみ $\boldsymbol{\varepsilon}_{t}$ に対する地盤ひず み䘽が式(7)から得られる.

(5)上記の (1)〜 (4)を想定されるトンネルひずみの範囲で繰 り返すと，図-9が得られる.

つまり,図-9の赤の実線と青の破線 2 本の折れ線は式(7) を表し，ひずみの伝達率は 1 以下のため，「地盤ひずみ= トンネルひずみ」の線より右側に存在する. 図中の折れ線 の鉄筋比大は $0.66 \%$ ，鉄筋比小は $0.24 \%$ で，図-8に対応し ている

鉄筋比の大小で, 同じ地艋ひずみに対してトンネルひず みが大きく変わるが，およそ図中の $[\mathrm{A}] \sim[\mathrm{C}]$ の状態 になる. [A] は躯体コンクリートにひびわれが無く、コ ンクリートが弓張に抵抗する範囲で, 地盤ひずみが増加し てもトンネルひずみがあまり増加しない様子が現れてい る. [B] はひびわれが生じ，ひびわれ部の鉄筋とコンク リートの付着が徐々に切れて自由になった鉄筋が伸びつ

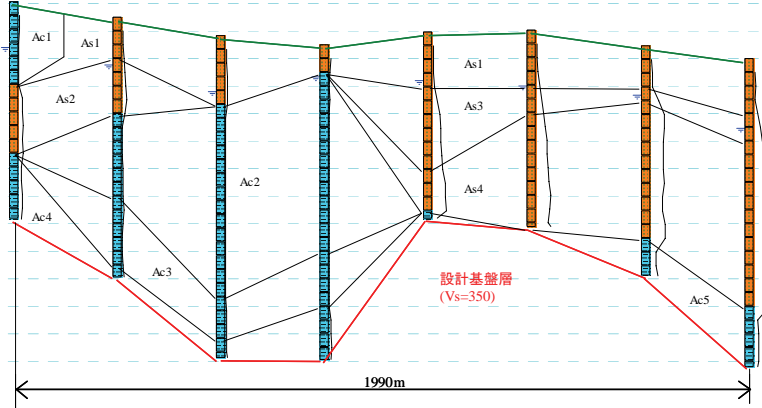

図-10 地盤状況

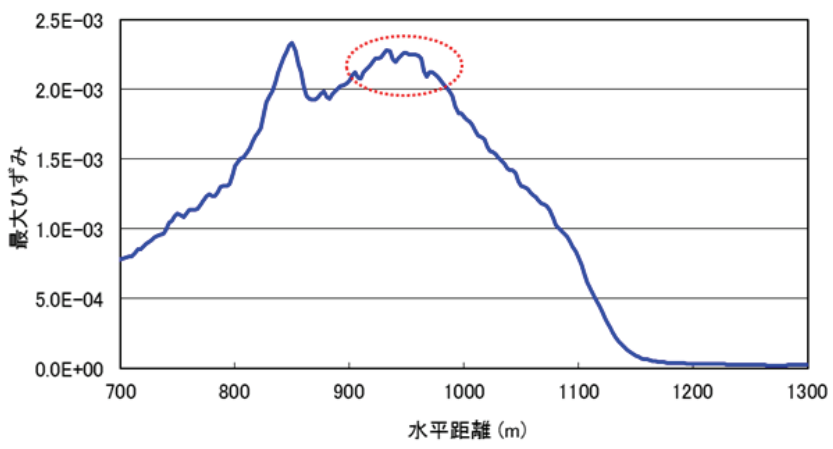

図-11 水平方向最大ひずみの分布

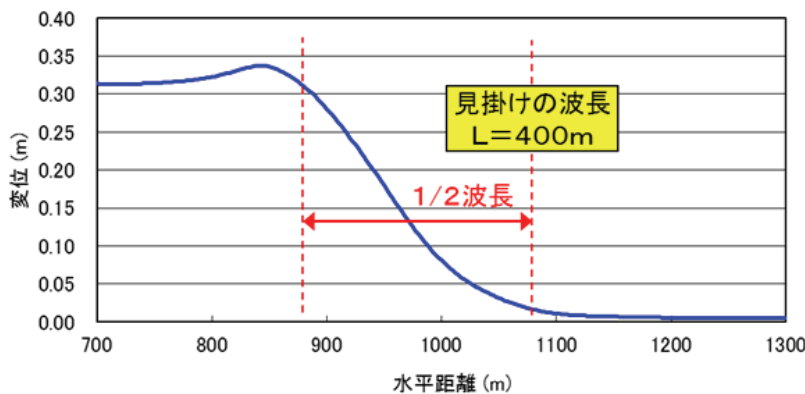

図-12 最大ひずみが生じた時刻の変位分布

つ抵抗する範囲， [C] は鉄筋が降伏し地盤ひずみの増加 と同じだけトンネル躯体のひずみが増加する範囲（「地盤 ひずタ=トンネルひずみ」の線と同じ傾きの範囲) である.

この図-9 では，トンネル躯体にひびわれが生じると， トンネル躯体の岡性が低下し伝達率 $\alpha$ が大きくなり，「ト ンネルひずタ＝地盤ひずみ」の関係に近づくため，［A］ の状態から [B] の状態へ移る時に図の左にシフトしてい る. 地震時に, 地盤ひずみが単調に増加していく状態を考 えると，図-9 の [A] の範囲の右端でトンネル躯体にひ びわれが発生すると, 矢印のように急激にトンネル躯体の ひずみが増加することが推測される。

なお，過去にひびわれが発生している場合やひびわれ発 生後の大きな摇れで, 再度ひずみが増加する場合は, 原点 から鉄筋の降伏点に向からルートを通る. 


\section{5. 動的解析による継手とひびわれの影響の検証}

\section{（1）地盤・トンネル・地震の条件}

東京の平野部に図-7 のトンネルがある場合の地震時挙 動について, これまで述べた継手周囲の土の抵抗とひびわ れを考慮した剛性がどのように影響するか, 動的解析を行 って確認した. 入力地震動は, 1995 年兵庫県南部地震神 戸ポートアイランド地中観測波（GL-32m・NS）とした.

対象地盤は，図-10のように而震設計基盤までの深さや 土質が急変する中央付近の箇所を選んで，トンネルに沿う 2 次元F EMの地盤モデルを作成した. 水平方向の地盤の 最大ひずみ分布は図-11 のようになり，水平距離 900〜 $1000 \mathrm{~m}$ の範囲で $0.20 \%$ を超える高まりがある. この範井の 最大ひずみはほぼ同時刻に発生しており, その1つの時刻 (6.43秒) での変位分布は図-12 のようであった.

表-4 トンネルの最大軸引張力と継手の開き

\begin{tabular}{|c|c|c|}
\hline ケース & $\begin{array}{c}\text { 最大軸力 } \\
(\mathrm{kN})\end{array}$ & $\begin{array}{c}\text { 継手の開き } \\
(\mathrm{cm})\end{array}$ \\
\hline (1)継手無し & 471,000 & 0 \\
\hline $\begin{array}{c}\text { (2)地盤の抵抗無視 } \\
\text { (継手1 箇所) }\end{array}$ & 62,500 & 7.7 \\
\hline $\begin{array}{c}\text { (3)地盤の抵抗考慮 } \\
\text { (継手1 }\end{array}$ & 362,000 & 2.1 \\
\hline $\begin{array}{c}\text { (4)地所) } \\
\text { (盤の抵抗考慮 } \\
\text { (継手3 箇所) }\end{array}$ & 261,000 & $1.3+1.5+1.3$ \\
\hline
\end{tabular}

表-5 トンネルの最大軸引張力と剛性低下範囲

\begin{tabular}{|c|c|c|c|}
\hline ケース & $\begin{array}{c}\text { 最大軸力 } \\
(\mathrm{kN})\end{array}$ & $\begin{array}{c}\text { 岡性低下部 } \\
\text { 平均ひずみ }\end{array}$ & $\begin{array}{c}\text { 岡性低下 } \\
\text { 範囲 }(\mathrm{m})\end{array}$ \\
\hline $\begin{array}{c}\text { (1)継手無し } \\
\text { ひびわ橅し) }\end{array}$ & 471,000 & - & - \\
\hline $\begin{array}{c}\text { (5)鉄筋少 } \\
(0.24 \%)\end{array}$ & 110,000 & $0.047 \%$ & 80 \\
\hline $\begin{array}{c}\text { (6)鉄筋多 } \\
(0.66 \%)\end{array}$ & 300,000 & $0.024 \%$ & 100 \\
\hline
\end{tabular}

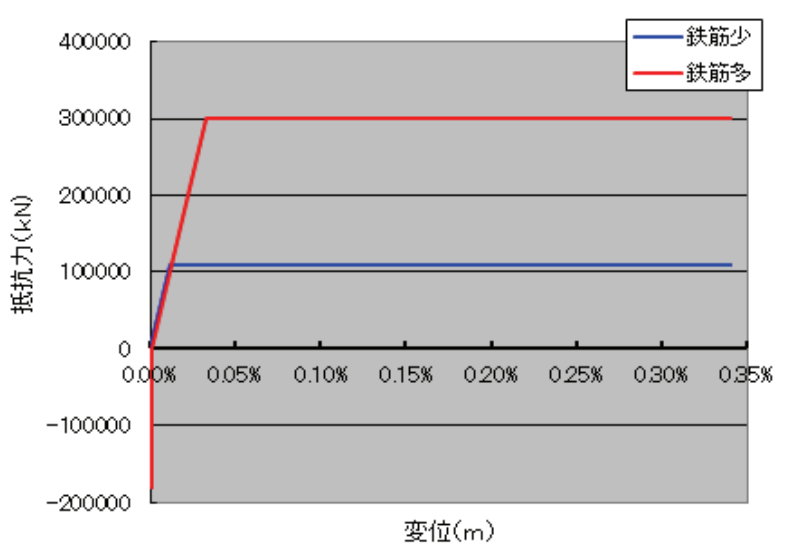

図-13バイリニア型の変位〜反力特性モデル
この分布は, 地盤急変部で最大ひずみが生じる時によく 見られる正弦波の $1 / 2$ 波長に近い分布形状である. 左右の 地盤で卓越周期が異なるために右の領域が動かず左の領 域が大きく摇れる振動モードが卓越した状態である.

\section{（2）継手周囲の土の抵抗ばねの影響}

着目する継手構造は, スリップバー式の引張抵抗のない 開削トンネルでは一般的な継手とする. 設計で考慮する継 手構造から決まる引張ばね定数 (気中でのばね定数) はゼ ロである. 継手周囲の土の断抵抗ばねは，前述 3 章 (4)の 抵抗範囲と式(2) を用いて評価する。高さ $h=15 \mathrm{~cm}$, 影響 面積 $A$ はトンネル軸方向の範囲 $1 \mathrm{~m} \times$ 全周長 $88 \mathrm{~m}$ より $88 \mathrm{~m}^{2}$. 地盤のせん断弾性係数 $G=20000 \mathrm{kN} / \mathrm{m}^{2}$ として, 式 (2) により算定すると, $\mathrm{Kg}=1.76 \times 10^{7} \mathrm{kN} / \mathrm{m}$ となる. 応答 解析の結果, トンネルの最大軸引張力と継手の開きは表 -4 のようになった.

従来の設計の考え方はケース(2)である. 継手を地盤ひず みが大きい地点近傍の施工目地に 1 箇所設置すると軸力 が大幅に下がりひびわれは発生しないが, 継手が $7.7 \mathrm{~cm}$ も 開くために連結鉄筋などで開きを抑制しないと止水性や 路面の連続性に問題があると評価されるものと思われる.

しかし実態は，3章で述べたように継手周囲の土のせん 断抵抗によりケース(3)となり, 継手の開きは $2.1 \mathrm{~cm}$ と大き くないが,この軸引張力は大きくひびわれを発生させるこ ととなり, 設計での想定と大きく異なる状態になる危険性 が高い.この例ではケース(4)のように，地盤ひずみが大き い地点に継手を $25 \mathrm{~m}$ 間隔で 3 箇所設置することが望まれ る.

\section{（3）ひびわれによる剛性低下の影響}

図-8 はコンクリートの引張抵抗を考慮したものである が, 既に何らかの原因でひびわれが発生している場合や最 初の大きな摇れでひびわれが発生し次の大摇れを受ける 場合は図-8 の特性を持つ場合より大きなひずみが発生す る. その場合を想定して，引張に対して初期岡性を持ち鉄 筋の降伏耐力で岡性が変わる図-13 のバイリニア型の特性 を持たせて, 非線形の応答変位法の解析を行った. 図中の 「鉄筋多」は $\mathrm{p}=0.66 \%$, 「鉄筋少」は $\mathrm{p}=0.24 \%$ であり， それぞれ降伏耐力は $3.00 \times 105 \mathrm{kN}$ および $1.10 \times 105 \mathrm{kN}$ で ある.この計算は, 継手のないトンネルの躯体にひびわれ が発生した後，摇れによって再度ひずみが増加し，ひびわ れ部の鉄筋が抜け出しながら抵抗する状況を計算したも のである.

解析の結果, トンネルの最大軸引張力と剛性低下範囲 が表-5 のようになった．表-5 の(5)のケースから，鉄筋 比に応じた最大軸力が発生していること, 岡性低下部の平 均ひずみは鉄筋比の大きいケース6)半減していること, 剛性低下範囲は鉄筋比の多い方が広がるが鉄筋比が 3 倍 になっても $25 \%$ しか広がらないことが分かる. 解析ケー スが少なく断定的な判断はできないが，トンネル縦断方向 の耐震性を確保するためには, 横断方向の設計で決まる配 力筋を配置するという考え方でなく, 積極的に発生ひずみ, 
すなわちトンネル躯体のひびわれ状態を制御する考え方 を取り入れて行くべきだと考える.

\section{6. トンネル縱断方向の耐震設計における継手の効 果とひびわれの影響の考慮に関するまとめ}

本論文は, シールド工法や開削工法で建設される都市卜 ンネルの維断方向の耐震設計法の問題を取り上げた. 筆者 らは, 継手周囲の地盤の抵抗により継手の岡性が設計より 大きくなることと, トンネル覆工のひびわれ発生後の剛性 を考慮した場合の地盤ひずみの増加に伴う覆工の状態変 化を示してきた ${ }^{13)}$ が，本論文では，継手の効果について 周囲の地盤の抵抗の評価法を見直して,ひびわれの影響と ともに実トンネルの事例を用いた試算を行い, それぞれの 影響の大きさを明らかにした. そして, 現行のトンネル縦 断方向の而震設計法に継手の効果とひびわれの影響を考 慮する方法を提案した. その要点は, 次の通りである.

a) 文献13)に示されたトンネルの継手周囲の土の抵抗ばね に物理的な解釈をすると,トンネル縦断方向に $1 \mathrm{~m}$ 程度, 高さ (厚さ) は $15 \mathrm{~cm}$ 程度までの継手周囲の土のせん断 抵抗ばねとして, 式(2)により評価できる.

b) 継手周囲の土の抵抗ばね定数はかなり大きく, 断面の あまり大きくないトンネルでは，図-6 のように，実卜 ンネルの構造のみの力学モデルから決定される継手ば ね定数（気中でのばね定数）と同程度になる.

c) 東京の平野部の実地盤を対象にして，上記 a),b)を考慮 した動的解析を行った結果, 継手の開きやトンネル躯体 に発生する軸引張力が現在の設計での想定と大きく異 なり，トンネル躯体には想定を超えるひびわれが発生す るものと考えられる.

d) 同じく上記 c) の解析から，トンネル縦断方向の鉄筋量 を増やすことによりトンネル躯体のひずみを抑制でき ることがわかる. 鉄筋量が少ない場合は, コンクリート にひびわれが生じると,ひびわれ部の鉄筋が降伏してひ びわれ部周辺には地盤ひずみとほぼ同じひずみが生じ ることとなる。

e) 上記d) の挙動は図-9から読み取れ，対象地盤に生じる トンネル縦断方向のひずみが分か水ば, 対象トンネルに 生じる平均ひずみの目安がわかる. 図-9 は, 地盤の動 的解析結果の情報加ら，3 章(3)の(1) (5)の手順で作成 することができる.

f) 図-9 より, 地震時のトンネル縦断方向の地盤ひずみが あまり大きくならない場所では, 継手に過度に期待せず に, 縦断方向の鉄筋を, その引張降伏強度を覆工コンク リートの引張強度を上回るように配置すれば, 覆工にひ びわれが生じても分散し, 覆工の平均ひずみを小さく押 さえることができる.

本論文で述べた継手の効果の問題については, 地盤と卜 ンネルを一体にした FEM モデルで解析を行ったことのあ
る方は気づいていることと思う。本論文で示した図-6 は 例であるが, 設計上無視できない影響があることは明らか である. 今後, 様々なトンネルで地震観則が行われ, 実挙 動の確認が行われることが期待される.

一方, 覆工のひびわれの影響については, 本論文で述心゙ た問題指摘と応答変位法て設計する意味を踏まえれば, 地 震や地盤の情報が必ずしも十分でないのに高精細なモデ ルを組み上げて力尽くで動的解析を行ったり, 継手の効果 に過度な期待をしたりしなくても, 比較的合理的な設計が 可能になるのではないかと考える. もちろん, 地震時の地 盤ひずみの発生が複雑であったり, トンネル構造が複雑で ひずみの発生が単純でないと考えられる特殊部は, その特 徵を的確に表したモデルによる動的解析が必要なことは 論を待たない. しかし, 構造計画の段階や比較的単純な区 間, 道路トンネルより径が小さく総延長の長いライフライ ンのトンネル等に対しては, 有用な方法と考えられる.

本論文は, 定量的な把握や誰でも使える設計法としてま とめるにはまだまだ詰めなければならない課題を残して いるが，トンネル縱断方向の耐震設計に重要な指摘と提案 ができたと考える.

\section{参考文献}

1）清宮理, 高橋正忠, 園田恵一郎: 沈埋トンネルの設計と施工, 技報堂出版，pp.119-141，2002.

2) 首都高速道路公団 : 東京港トンネル工事誌, 土木学会, pp.463-558, 1977.

3) 土木学会トンネル工学委員会技術小委員会シールドトンネル の耐震設計法検討部会 : シールドトンネルの耐震検討, トン ネルライブラリー第19号, pp.145-181, 2007.

4) 和佐勇次郎, 吉田幸司, 田中努 : 軟弱地盤中のシールドトン ネルの地盤抢よび覆工岡性急変部の而震設計法, 土木学会論 文集，No.510/IV-26, pp.69-79, 1995.

5) 中川誠志, 式田直孝, 田中努, 大竹省吾 : 硬質地盤を通過寸 る剛性の高いトンネルの地震時応答性状と耐震設計, 土木学 会論文集，No.516／VI-27，pp.41-51，1995.

6) 鈴木猛康 : シールドトンネル軸方向の而震性評価に関する考 察，土木学会論文集，No.441／I-18, pp.137-146, 1992.

7) 田中努, 橘義則, 大竹省吾 : ひびわれ部の剛性を考慮した卜 ンネル覆工の耐震設計法, トンネル工学研究発表会論文・報 告集, 第3巻, pp.219-224, 1993.

8）塚田あゆみ，橘義則，田中努：ひびわれを考慮した地中構造 物の軸引張剛性の評価法に関する研究, トンネル工学研究発 表会論文・報告集, 第7巻, pp.355-360, 1997.

9) 岡村甫, 前川宏一:鉄筋コンクリートの非線形解析之構成則, 技報堂出版，pp.1-182，1991.

10）株式会社フォーラムエイト:UC-win/WCOMD Ver.2 電子マニ ユアル, 2006.

11) (社)日本道路協会 : 共同溝設計指針, 丸善, pp.52-80, 1986.

12）日本水道協会: 水道施設而震工法指針・解説, pp.87-91, 2009.

13）田中努，金井拓弥，鈴木猛康：継手とひびわれの影響を考慮 したトンネル縦断方向の地震時挙動と軸岡性の評価, 土木学 会論文集 A1 (構造·地震工学) Vol. 68(2012) No. 4, p.I_867-I_875, 
2012.

14) 西岡勉，運上茂樹 : 線状地中構造物における地震時の軸ひず み伝達特性に関する研究，構造工学論文集，Vol.49A，pp.
1199-1208, 2002.

(2012.11. 16 受付, 2013.1.23 修正, 2013.2.23 受理)

\section{SEISMIC DESIGN OF TUNNELS IN THE LONGITUDINAL DIRECTION IN CONSIDERATION OF THE EFFECT OF JOINTS AND CRACKS}

\section{Tsutomu TANAKA and Takeyasu SUZUKI}

In this paper, the authors reexamined the evaluation method, proposed previously by the authors, on the effect of opening of joints on soil constraint around a tunnel, first. Then, the authors reevaluated joint stiffness of actual tunnels and the influence of the use of such stiffness on earthquake response results of tunnels. Next, earthquake response analyses were conducted in consideration of stiffness degradation of tunnel lining due to cracking, and results of the earthquake response analyses were evaluated. Finally, based on such examinations, the authors summarized a new earthquake resistant design method, taking consideration of the features as follows. Reinforcing bars in the longitudinal direction should be arranged so that the tensile yield strength of reinforcing bars may become greater than the ensile strength of concrete lining, without over evaluating joint behavior, in the area where earthquake ground strain is not large, In the area where ground strain is large, on the contrary, average strain of tunnel lining should be reduced, by arranging joints in consideration of soil constraint around a tunnel. 